\title{
PENGGUNAAN PEN TABLET DENGAN APLIKASI GOOGLE MEET UNTUK MENINGKATKAN HASIL BELAJAR MATEMATIKA SMK
}

\author{
NURAINI \\ SMKN 5 Kota Serang \\ e-mail: mozakennard@gmail.com
}

\begin{abstract}
ABSTRAK
Best Practice ini dilaksanakan untuk meningkatkan hasil belajar matematika SMK melalui penggunaan Pen Tablet dengan aplikasi Google Meet. Subyek dari penelitian ini adalah siswa SMKN 5 Kota Serang kelas XII OTKP dan XII TKJ yang berjumlah 155 orang yang dilakukan pada semester ganjil tahun ajaran 2021/2022 dengan materi : Geometri Dimensi Tiga, Statistika dan Peluang. Best Practice ini menggambarkan tentang proses pembelajaran menggunakan media berupa Pen Tablet dengan aplikasi Google Meet. Data kuantitatif diperoleh dari nilai ulangan harian dengan teknik test tertulis bentuk uraian, sedangkan data kualitatif diperoleh dari hasil observasi keaktifan siswa. Setelah siswa diajarkan matematika menggunakan Pen Tablet dengan aplikasi Google Meet hasil belajar meningkat sebesar 24,6\% dari rata-rata materi bab 1 62,00 meningkat terus pada materi bab 3 menjadi 77,25. Pelaksanaan Best Practice menunjukkan bahwa penggunaan Pen Tablet dengan aplikasi Google Meet dapat meningkatkan hasil belajar matematika siswa SMK terutama siswa kelas XII OTKP dan XII TKJ SMKN 5 Kota Serang semester ganjil tahun ajaran 2021/2022.
\end{abstract}

Kata Kunci: Pen Tablet, Google Meet, Hasil Belajar

\section{ABSTRACT}

This Best Practice is implemented to improve mathematics learning outcomes of vocational through the use of a Pen Tablet with the Google Meet application. The subjects of this study were 155 students of SMKN 5 Kota Serang class XII OTKP and XII TKJ who were conducted in the odd semester of the 2021/2022 academic year with the material: Three Dimensional Geometry, Statistics and Probability. This Best Practice describes the learning process using media in the form of a Pen Tablet with the Google Meet application. Quantitative data were obtained from daily test scores with written test techniques in the form of descriptions, while qualitative data were obtained from observations of student activity. After students were taught mathematics using Pen Tablet with the Google Meet application, learning outcomes increased by $24.6 \%$ from the average chapter 1 material of 62,00 which continued to increase in chapter 3 material to 77.25. The implementation of Best Practice shows that the use of the Pen Tablet with the Google Meet application can improve the mathematics learning outcomes of SMK students, especially students of class XII OTKP and XII TKJ SMKN 5 Kota Serang in the odd semester of the 2021/2022 academic year.

Keywords: Pen Tablet, Google Meet, Learning Outcomes

\section{PENDAHULUAN}

Sistem pembelajaran daring yang berlaku di Indonesia sejak bulan Maret 2019 menyebabkan kejenuhan di kalangan peserta didik baik tingkat dasar maupun tingkat lanjut, karena iklim belajar yang diciptakan pembelajaran daring sangat mempengaruhi motivasi belajar. Dalam pembelajaran tatap muka guru dapat menciptakan suasana kelas kondusif yang bisa menjaga motivasi belajar siswa. Iklim kelas memiliki pengaruh yang signifikan dengan motivasi belajar, namun kondisi tersebut tidak terjadi pada pembelajaran daring, siswa dan guru yang sebelumnya berinteraksi secara langsung dalam ruang kelas yang bebas, sekarang harus berinteraksi dalam ruang virtual yang terbatas sehingga pada akhirnya mempengaruhi hasil belajar siswa.

Untuk mengatasi hal tersebut guru dituntut memberikan berbagai strategi pembelajaran yang sesuai dengan pembelajaran daring dengan menciptakan suasana belajar yang kondusif, 
kreatif dan inovatif. Guru dituntut menggunakan media pembelajaran yang tepat agar siswa dapat memahami materi pelajaran sehingga tujuan pembelajaran dapat tercapai. Dalam mengakomodir kebutuhan tersebut diperlukan pemilihan media pembelajaran yang tepat, tentunya media yang mampu memperjelas penyajian pesan supaya siswa termotivasi belajar walaupun belajar secara virtual. Sarana pembelajaran daring yang telah digunakan sebagian besar guru antara lain WhatsApp, Google Classroom, Zoom, Google meet dan lain-lain. Sebagian besar guru memanfaatkan bahan ajar dalam bentuk Power Point dan video pembelajaran. Video pembelajaran dapat dibuat sendiri oleh guru, diupload dari youtube atau diperoleh dari situs TV edukasi, e-learning dan lain sebagainya, karena video pembelajaran dianggap dapat memenuhi kebutuhan siswa dalam belajar virtual seperti artikel yang ditulis oleh Machfud (2021) meneliti tentang efektifitas penggunaan media video pembelajaran pada masa pandemi covid 19. Dalam artikel tersebut Machfud memberi kesimpulan bahwa media berupa video pembelajaran efektif digunakan pada masa pandemi Covid-19, karena memudahkan guru dalam menyampaikan materi yang perlu adanya penjelasan lebih detail serta memudahkan peserta didik memahami materi pembelajaran.

Terkait hasil penelitian tersebut, penulis berpendapat video pembelajaran efektif untuk semua mata pelajaran karena dapat mengurangi rasa bosan peserta didik. Namun untuk pembelajaran matematika, khususnya pada SMKN 5 Kota Serang, berdasarkan pengalaman penulis hasil belajar menggunakan video pembelajaran masih belum mampu mencapai hasil belajar yang diharapkan seperti yang diperoleh saat tatap muka, karena siswa terbiasa mendapat materi berdasarkan penjelasan dari guru langsung yang ditulis langkah demi langkah di papan tulis dan guru terbiasa mendorong siswa menyelesaikan soal bersama. Untuk itu penulis berinisiatif menggunakan Pen Tablet dalam menjelaskan materi pelajaran disesuaikan dengan karakteristik siswa dan karakteristik materi pelajaran serta gaya belajar siswa. Dalam pemeblajaran daring Pen Tablet dapat mengantikan fungsi papan tulis di kelas sehingga guru dapat menjelaskan langkah demi langkah sesuai kemampuan siswa, layaknya pembelajaran di kelas, perbedaannya hanyalah penggunaan Pen Tablet dilakukan secara virtual dengan bantuan aplikasi Google Meet. Penggunaannya disesuaikan dengan karakteristik mata pelajaran matematika yang membutuhkan perhitungan secara rinci dan bertahap disertai gambar, tabel dan grafik.

Pada pelaksanaannya, penulis menggunakan aplikasi Google Meet dalam penggunaan Pen Tablet karena Google Meet menunjang kebutuhan siswa dan guru, siswapun sudah terbiasa menggunakannya sejak diberlakukannya pembelajaran daring. Penggunaan Pen Tablet dan aplikasi Google Meet memiliki fungsi yang bermakna bagi penulis karena berpengaruh terhadap motivasi belajar siswa. Sudjana dan Rivai yang dikutip oleh Sundayana, tentang fungsi media pembelajaran bahwa media pembelajaran adalah salah satu unsur yang harus dikembangkan oleh pendidik dalam mewujudkan situasi belajar mengajar efektif yang merupakan bagian integral dari keseluruhan situasi mengajar, dimana dalam penggunaannya harus melihat tujuan dan materi pelajaran, penggunaannya pun harus dapat melengkapi proses pembelajaran supaya lebih menarik perhatian peserta didik, sehingga dapat mempercepat proses pembelajaran dan dapat membantu siswa dalam memahami materi yang disampaikan oleh guru (Sundayana, 2013). Berdasarkan fungsi media yang diungkapkan oleh Sudjana dan Rivai, pemilihan media Pen Tablet menggunakan aplikasi Google Meet dianggap memiliki fungsi yang yang dapat membantu peserta didik belajar dengan suasana yang menyenangkan dan membuat lebih termotivasi sehingga siswa dapat memahami materi yang konkret hingga abstrak dan pada akhirnya tujuan pembelajaran tercapai dengan baik.

Pen Tablet atau Tablet grafis (Inggris: Graphic Tablet) adalah perangkat keras peranti masukan komputer yang membolehkan pemakainya untuk menggambar dengan tangan dan memasukkan gambar atau sketsa langsung ke komputer, layaknya menggambar di atas kertas menggunakan pensil. Pen Tablet adalah alat grafis yang digunakan oleh ilustrator dan komikus, fungsinya agar dapat langsung menggambar di komputer (Ernes, 2017). Pen Tablet berguna untuk membantu pengguna yang aktif dalam bidang desain grafis, desain komunikasi visual, 
desain interior untuk mencitrakan image seperti seakan-akan mereka sedang menggambar langsung melalui kertas dan menggunakan pensil (Lubis, dkk, 2020) Dalam Best practice yang telah dilakukan oleh Mafidah (2021), Penggunaan Pen Tablet memungkinkan pengajar untuk menyertakan konten informasi seperi tabel, grafik, simbol simbol matematika dan diagram yang rumit, dimungkinkan juga untuk menandai slide, membubuhi keterangan pada gambar atau memberikan komentar. Sehingga guru dapat menyampaikan seluruh materi dengan jelas karena dibantu oleh fitur-fitur yang ada pada Pen Tablet. Dengan Pen Tablet pembelajaran matematika khususnya untuk siswa kelas XII SMK menjadi lebih menyenangkan, langkahnya hampir sama dengan pembelajaran di kelas, walau di lakukan pada Google Meet karena setiap langkah guru menjelaskan siswa dapat bertanya langsung dan menjawab serta bersama-sama menyelesaikan suatu persoalan matematika hingga selesai. Pembelajaran dengan menggunakan Pen Tablet pada Google Meeting dapat direkam guru dan diputar kembali oleh siswa sesuai kebutuhan siswa masing-masing, sehingga siswa dapat memahami materi pelajaran yang dipelajari dan hasil belajarnya meningkat.

Berdasarkan uraian tersebut di atas, tujuan dibuatnya Best Practice ini adalah mendeskripsikan pengalaman penulis melalui pengunaan Pen Tablet untuk meningkatkan hasil belajar Matematika SMK dengan aplikasi Google Meet.

\section{METODE PELAKSANAAN}

Jenis penelitian yang telah dilaksanakan penulis tentang Pen Tablet ini adalah Best Practice. Laporan Best Practice ini ditulis berdasarkan pengalaman terbaik dalam upaya meningkatkan hasil belajar siswa yang telah penulis lakukan selama pembelajaran daring matematika SMK. Data Best Practice terdiri dari dua jenis, antara lain : (1) Data kuantitatif, diperoleh dari nilai ulangan harian siswa dengan teknik test tertulis, (2) data kualitatif, diperoleh dari hasil observasi keaktifan siswa dengan menggunakan lembar observasi keaktifan belajar siswa. Hasil perolehan data tersebut dianalisis dan digambarkan dalam bentuk tabel dan grafik.

Best Practice dilaksanakan di SMKN 5 Kota Serang, Banten pada semester ganjil tahun ajaran 2021/2022 mulai tanggal 26 Juli sampai 26 November 2021. Adapun subyek dari penelitian ini adalah siswa SMKN 5 Kota Serang kelas XII OTKP 1, XII OTKP 2, XII TKJ 2 dan XII TKJ 3 yang berjumlah 155 siswa, dengan karakteristik mayoritas siswa aktif dan tidak ada kendala dalam pembelajaran daring menggunakan gadget, karena seluruh siswa memilikinya. Materi yang diajarkan adalah seluruh materi kelas XII SMK pada semester ganjil, antara lain : Dimensi Tiga, Statistika dan Peluang. Penulis menggunakan Laptop, Hp Android dan Pen Tablet sebagai media pembelajaran daring dengan bantuan berbagai aplikasi seperti : WhatsApp Group untuk komunikasi langsung dengan siswa, Google Meet untuk menyampaikan materi secara virtual, Google Classroom untuk mengumpulkan tugas dan ulangan harian.

\section{HASIL DAN PEMBAHASAN}

\section{Hasil}

Best Practice ini telah dilakukan terhadap 155 siswa dari 4 kelas XII SMKN 5 Kota Serang, yakni : 2 kelas Program Studi Otomatisasi Tata Kelola Perkantoran (OTKP 1 dan OTKP 2) dan 2 kelas Program Studi Teknik Komputer Jaringan (TKJ 2 dan TKJ 3), masing masing kelas rata- rata berjumlah hampir 40 siswa. Sebelum pembelajaran daring dimulai, siswa telah memperoleh Modul Matematika kelas XII dalam format Pdf yang dikirim pada WA Group kelas. Pelaksanaan Best Practice dilakukan secara bertahap, sebagai berikut :

1. Materi 1 : Geometri Dimensi Tiga

Alokasi waktu untuk materi Geometri Dimensi Tiga terdiri dari 12 kali pertemuan yang dilakukan pada tanggal 26 Juli sampai tanggal 3 September 2021. Pada pertemuan ke-1, 3, 5 dan 7, guru memberikan materi berupa video pembelajaran melalui Google Classroom dan siswa diminta menulis namanya di forum Google Classroom pada kolom komentar untuk memastikan telah menyimak video dan sebagai kelengkapan absensi siswa. Video 
pembelajaran materi Geometri Dimensi Tiga diperoleh dari channel Youtube m4th-lab dan video yang dibuat sendiri oleh penulis selaku guru, video pembelajaran yang dibuat sendiri juga diupload dalam Youtube dengan channel Aini Nuraini. Pada pertemuan ke-2, 4, 6 dan 8, guru memberikan tugas mandiri melalui Google Classroom. Pada pertemuan ke-9 dan 10 dilakukan penguatan dengan memberikan soal-soal latihan. Pada pertemuan ke-11 dilakukan penilaian harian dan pertemuan terakhir dilakukan penilaian harian remedial dan susulan

2. Materi 2 : Statistika

Alokasi waktu untuk materi Statistika terdiri dari 13 kali pertemuan yang dilakukan pada tanggal 6 September sampai tanggal 20 Oktober 2021. Pada pertemuan ke 1, 3, 5, 7 dan 9, guru memberikan materi secara langsung menggunakan Pen Tablet berbantuan Google Meet selama 90 menit ( 2 X 45 menit). Dengan Pen Tablet siswa dijelaskan secara rinci materi yang dipelajari. Pada pertemuan ke 2, 4, 6, 8 dan 10, guru memberikan tugas mandiri melalui Google Classroom. Pada pertemuan ke-11 dilakukan penguatan dengan memberikan soal-soal latihan. Pada pertemuan ke-12 dilakukan penilaian harian dan pertemuan terakhir dilakukan penilaian harian remedial dan susulan.

3. Materi 3 : Peluang

Alokasi waktu untuk materi Peluang terdiri dari 11 kali pertemuan yang dilakukan pada tanggal 21 Oktober sampai 26 November 2021. Pada pertemuan ke 1, 3, 5 dan 7, guru memberikan materi secara langsung menggunakan Pen Tablet berbantuan Google Meet selama 90 menit ( 2 X 45 menit). Dengan pen tablet siswa dijelaskan secara rinci materi yang dipelajari. Pada pertemuan ke 2, 4, 6 dan 8, guru memberikan tugas mandiri melalui Google Classroom. Pada pertemuan ke-9 dilakukan penguatan dengan memberikan soalsoal latihan. Pada pertemuan ke-10 dilakukan penilaian harian dan pertemuan terakhir dilakukan penilaian harian remedial dan susulan.

Berikut ini adalah langkah-langkah pembelajaran menggunakan Pen Tablet dengan

Google Meet,:

1. Hubungkan Pen Tablet pada laptop

2. Buka browser Chrome pada laptop. Pada pembelajaran dengan bantuan google ini penulis selaku guru menggunakan akun guru belajar id, agar pembelajaran dapat direkam.

3. Pilih meet pada menu Google

4. Klik start a meeting, Buat undangan meeting dan share ke grup WA siswa

5. Setelah semua siswa dipastikan masuk, klik record meeting untuk merekam kegiatan pembelajaran

6. Pada kegiatan Pendahuluan, sebelum memulai pembelajaran guru melakukan apersepsi seperti : berdoa, mengecek kehadiran siswa, mengecek kelengkapan belajar dan memotivasi siswa dengan memberikan pertanyaan-pertanyaan yang berkaitan dengan materi pembelajaran dilanjutkan dengan menyampaikan tujuan pembelajaran.

7. Pada kegiatan inti, siswa siap untuk menerima penjelesan dari guru, klik more option pada bagian bawah layar, pilih whiteboard, klik start a new whiteboard dan kita akan memperoleh Jamboard File, agar semua siswa dapat melihat Jamboard File guru, klik precent a meeting pada bagian atas layar, lalu share, set background, tambahkan gambar yang dibutuhkan dan sesuaikan dengan materi agar tampilan Jamboard atau papan tulis digital lebih menarik

8. Saat menjelaskan materi dengan memberikan contoh soal beserta langkah penyelesaiannya, guru terus berinteraksi dengan siswa dan membiarkan soal diselesaikan bersama-sama agar siswa selalu berkonsentrasi selama pembelajaran berlangsung, diakhiri dengan pemberian ucapan selamat bagi siswa yang dapat menyelesaikan soal dengan benar.

9. Guru memberi latihan soal untuk dikerjakan masing-masing siswa, dan hasilnya dibahas bersama pada Jamboard File

10. Pada kegiatan penutup, guru membimbing siswa untuk membuat intisari tentang materi yang telah dipelajari. Guru menyarankan siswa untuk bertanya melalui WA group apabila 
ada penjelasan materi atau contoh soal yang masih kurang dimengerti selama pembelajaran.

11. Guru menutup kegiatan pembelajaran dengan mengucap hamdalah dan siswa diperkenankan meninggalkan meeting dengan ucapan salam

12. Pada menu google meet pilih stop recording untuk menyelesaikan proses perekaman pembelajaran.

13. Pembelajaran selesai.

Untuk menguatkan hasil pelaksanaan Best Practice, berikut ini penulis tampilkan dokumentasi pelaksanaannya, antara lain hasil screenshot foto siswa dan hasil screenshot salah satu materi yang diajarkan.

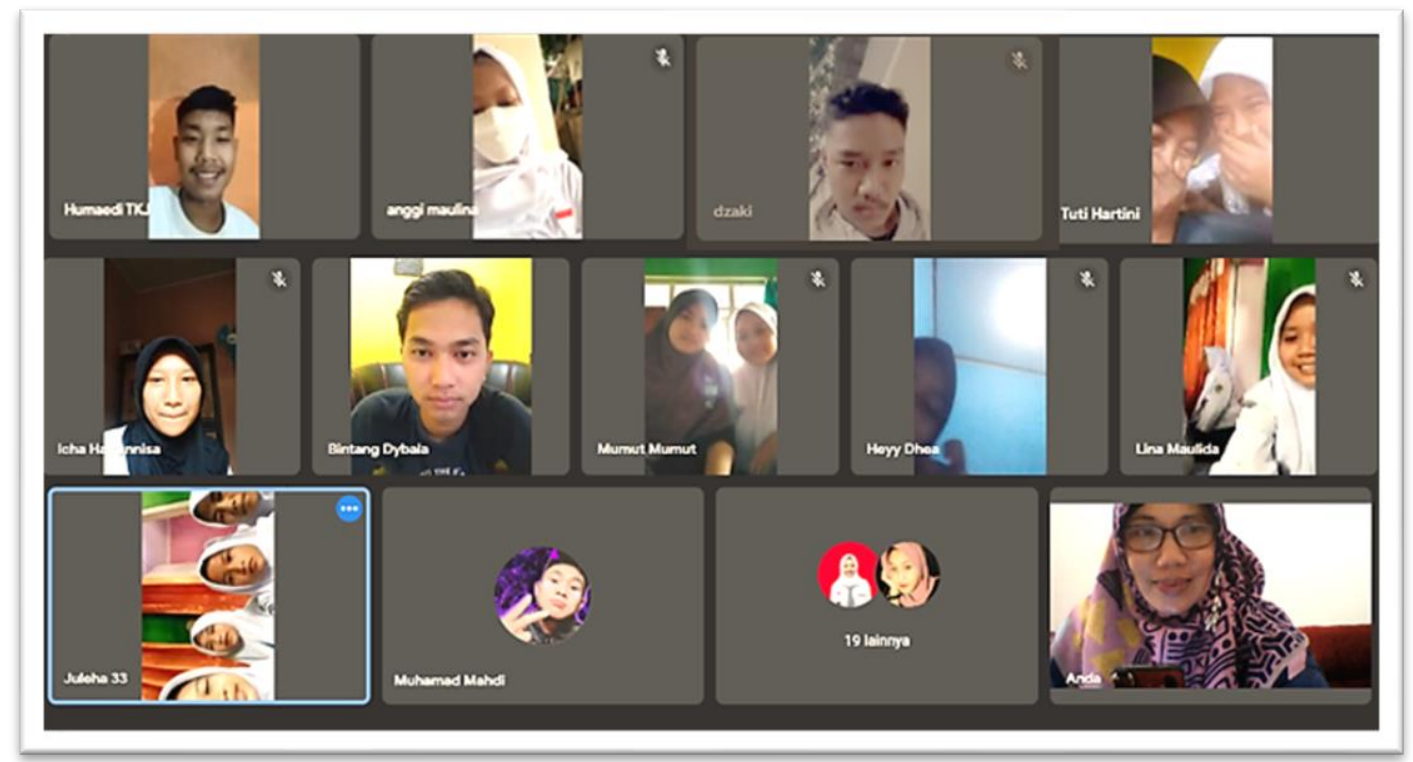

\section{Gambar 1. Foto Siswa Saat Pembelajaran}

Gambar tersebut menampilkan foto siswa yang hadir dalam pembelajaran. Pada saat pembelajaran berlangsung guru menjelaskan materi sekaligus melakukan observasi terhadap siswa, guru selalu mencatat siswa yang aktif bertanya dan siswa yang menyelesaikan soal latihan saat pertemuan. Siswa hadir hampir $100 \%$ pada setiap pertemuan walaupun di antara siswa ada yang menggunakan satu akun untuk beberapa orang karena siswa yang bersangkutan sedang kendala dengan kuota . Sebagian besar siswa turut serta aktif mengikuti pembelajaran langkah demi langkah hingga pembelajaran selesai. Siswa terlihat antuasias dalam menyimak materi walau ada beberapa di antara mereka terhambat koneksi internet namun semua itu dapat segera dikendalikan

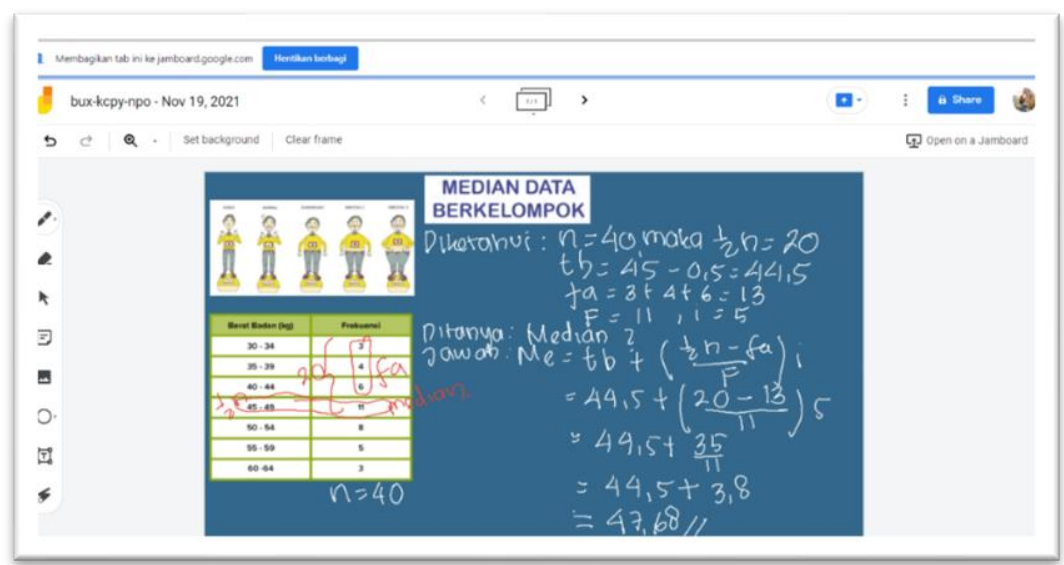

Gambar 2. Tampilan Materi yang Dihasilkan Pen Tablet pada Jamboard File Google Meet 
Gambar tersebut menampilkan salah satu materi yang diajarkan menggunakan Pen Tablet, yakni materi tentang Statistika. Guru menampilkan gambar yang telah didownload dari internet untuk memberikan penguatan terhadap materi yang diajarkan sehingga dapat menarik minat siswa untuk belajar, sebelum contoh soal diberikan, guru menampilkan gambar serta tabel dan melakukan apersepsi terhadap gambar yang ditampilkan tersebut.

Setiap akhir materi dilakukan ulangan harian dengan teknik test tertulis bentuk uraian. Berikut ini hasil nilai ulangan yang diperoleh masing masing kelas sejak bulan Juli hingga November 2021 dengan Kriteria Ketuntasan Minimum (KKM) sebesar 75

Tabel 1. Nilai Rata-rata Ulangan Harian Siswa Setiap Kelas Per Materi

\begin{tabular}{|c|c|c|c|}
\hline No. & Kelas & Materi & Nilai Rata-rata \\
\hline \multirow[t]{3}{*}{1} & XII OTKP 1 & Geometri Dimensi Tiga & 61 \\
\hline & & Statistika & 76 \\
\hline & & Peluang & 78 \\
\hline \multirow[t]{3}{*}{2} & XII OTKP 2 & Geometri Dimensi Tiga & 55 \\
\hline & & Statistika & 75 \\
\hline & & Peluang & 77 \\
\hline \multirow[t]{3}{*}{3} & XII TKJ 2 & Geometri Dimensi Tiga & 65 \\
\hline & & Statistika & 75 \\
\hline & & Peluang & 76 \\
\hline \multirow[t]{3}{*}{4} & XII TKJ 3 & Geometri Dimensi Tiga & 67 \\
\hline & & Statistika & 76 \\
\hline & & Peluang & 78 \\
\hline
\end{tabular}

Data pada tabel 1 menunjukan bahwa nilai rata-rata ulangan harian yang diperoleh siswa pada materi Geometri Dimensi Tiga masih jauh dari KKM $(<75)$, hal ini disebabkan oleh pembelajaran yang hanya menggunakan video pembelajaran tanpa adanya interaksi langsung dengan siswa. Sementara nilai rata-rata ulangan harian materi Statistika dan Peluang yang diperoleh siswa meningkat setelah dilakukan pembelajaran daring menggunakan Pen Tablet dengan bantuan aplikasi Google Meet. Data tabel tersebut dijelaskan lebih mendetail dalam tabel berikut :

Tabel 2. Nilai Rata-rata Ulangan Harian Setiap Materi dari Seluruh Kelas

\begin{tabular}{ccc}
\hline No. & Materi & Nilai Rata-rata \\
\hline 1 & Geometri Dimensi Tiga & 62,00 \\
2 & Statistika & 75,50 \\
3 & Peluang & 77,25 \\
\hline
\end{tabular}

Tabel 2 menunjukkan bahwa nilai rata-rata ulangan harian yang diperoleh siswa pada materi Geometri Dimensi Tiga jauh di bawah KKM, sedangkan nilai rata-rata ulangan harian pada materi Statistika dan Peluang sudah mencapai KKM (>75), Rincian nilai Tabel 2 diperkuat oleh grafik berikut ini : 


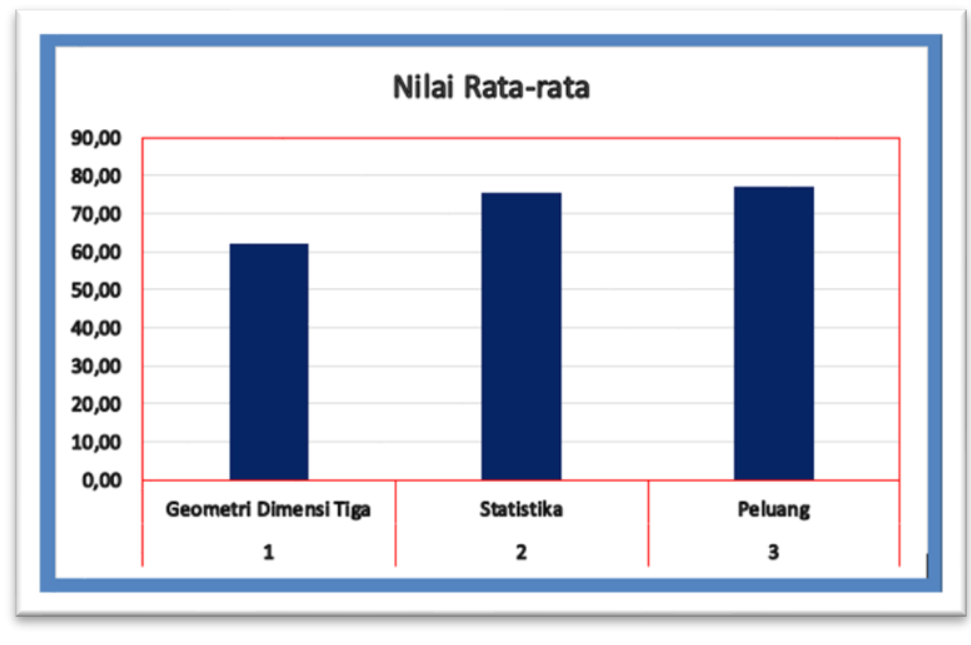

Gambar 4. Grafik Nilai Rata-rata Ulangan Harian

Gambar 4 menunjukkan adanya peningkatan yang signifikan pada nilai rata-rata ulangan harian materi kedua dan ketiga setelah guru menggunakan Pen Tablet dengan bantuan aplikasi Google Meet. Pada materi pertama rata-rata hanya 62 hingga mencapai 77, 25 pada materi ketiga.Itu berarti ada kenaikan nilai rata-rata sebesar $24,6 \%$.

\section{Pembahasan}

Pada Tabel 1 untuk materi Geometri dimensi tiga nilai rata-rata yang diperoleh siswa kurang dari KKM, hal ini membuktikan bahwa penggunaan video pembelajaran yang dibagikan ke siswa melalui Google Classroom belum mampu meningkatkan hasil belajar matematika siswa SMK secara maksimal. Dengan teknik seperti itu guru tidak bisa memantau berapa banyak siswa yang mengunduh dan menyimak video. Siswa hanya dibagikan video saja, absen diri di Google Classroom setelah itu mengerjakan soal-soal. Pembahasan latihan soal dilakukan sendiri oleh guru dalam bentuk video yang kembali dibagikan lagi pada Google Classroom. Dengan Kondisi seperti ini pembelajaran tidak dapat berjalan dengan baik, pasif dan tidak terkontrol sehingga dapat dikatakan pendekatan yang guru lakukan pada materi 1 kurang berhasil walaupun nilai rata-ratanya lebih tinggi dibandingkan sebelum menggunakan video atau masih menggunakan Power Point dan modul.

Dengan kompetensi yang dimiliki guru di bidang teknologi dan keinginan kuat untuk meningkatkan hasil belajar siswa selama daring, pada materi Statistika dan Peluang hasil belajar siswa mengalami peningkatan yang cukup signifikan karena pembelajarannya menggunakan Pen Tablet dengan bantuan Google Meet. Saat menjelaskan materi dengan memberikan contoh soal beserta langkah penyelesaiannya, guru terus berinteraksi dengan siswa dan mendorong siswa menyelesaikan soal bersama-sama sehingga siswa berperan aktif dan konsentrasi terhadap materi yang dipelajarinya, ditambah reward yang guru berikan saat siswa mampu menyelesaikan soal dengan benar, cara ini semakin menambah gairah belajar. Dengan Pen Tablet saat meeting langkah belajar dan suasananya tidak jauh beda dengan suasana belajar di kelas hanya saja pembelajaran ini terjadi secara virtual.

Berdasarkan uraian tersebut terbukti bahwa penggunaan media pembelajaran Pen Tablet dengan Google Meet mampu memberikan kemudahan dan kejelasan atas materi yang diberikan kepada siswa dan mampu meningkatkan keaktifan siswa dalam belajar, sehingga hasil belajar juga meningkat. Dengan Pen Tablet siswa diberi penjelasan materi seperti layaknya di dalam kelas, bahkan lebih dari itu materi yang telah diajarkan dapat diulang kembali oleh siswa sesuai kebutuhan karena pembelajaran dapat direkam dan dijadikan video, dan mampu menguatkan pemahaman siswa terhadap materi. Peningkatan hasil belajar ini tidak luput dari adanya penggunaan media yang lebih dari satu, yakni Pen Tablet, Google Meet dan Modul. Hal ini sejalan dengan pendapat Zaidah (2021) bahwa "informasi pembelajaran memerlukan lebih dari satu media untuk mendorong siswa memahami pembelajaran daring dan 
semakin sering pendidik melakukan pendekatan maka semakin baik respon yang diperoleh". Pendekatan yang terjadi dalam Best Practice ini adalah adanya langkah pembelajaran efektif yang guru ciptakan serta komunikasi antar guru dan siswa saat menjelaskan materi pada Google Meet menggunakan Pen Tablet. Dengan begitu Penggunaan Pen Tablet dianggap efektif untuk pembelajaran matematika.

Secara umum Best Practice ini mendukung temuan Best Practice yang dilakukan oleh Mafidah (2021) dengan judul "Efektivitas Video Pembelajaran Matematika pada Materi Dimensi Tiga dengan Menggunakan Pen Tablet" Pada Best Practicenya diperoleh hasil belajar siswa meningkat setelah diberi treatment berupa video pembelajaran yang dibuat menggunakan Pen Tablet. Bedanya dengan Best Practice ini, Pen Tablet digunakan secara langsung dengan Google Meet, disaat yang sama siswa berinteraksi dan melihat langkah-langkah yang guru berikan secara langsung. Dengan demikian jelaslah bahwa penggunaan Pen Tablet dengan Google Meet dapat meningkatkan hasil belajar matematika siswa SMK.

\section{KESIMPULAN}

Berdasarkan hasil dan pembahasan, dapat ditarik kesimpulan sebagai berikut :

1. Pen tablet dapat digunakan sebagai salah satu media pembelajaran jarak jauh yang efektif khususnya untuk mata pelajaran matematika

2. Penggunaan Pen Tablet dengan Google Meet dapat meningkatkan keaktifan siswa dalam belajar matematika

3. Penggunaan Pen Tablet dengan Google Meet dapat meningkatkan hasil belajar matematika SMK

4. Penggunaan Pen Tablet dengan Google Meet memberikan dampak yang baik terhadap peningkatan kualitas pembelajaran matematika khususnya pada siswa kelas XII OTKP 1, XII OTKP 2, TKJ 2 dan TKJ 3 SMKN 5 Kota Serang.

\section{DAFTAR PUSTAKA}

Ernes, Stella. (2017). Saat Aku Besar Nanti : Aku Ingin Menjadi Desainer Grafis. Jakarta : Buana Ilmu Popular.

Lubis, dkk. (2020). Pengenalan Teknologi Informasi. Medan : Yayasan Kita Menulis

Machfud. (2021). Efektivitas Penggunaan Media Video Pembelajaran di SMP Negeri 2 Tarakan

Pada Masa Pandemi Covid-19. Edutech : Jurnal Inovasi pendidikan Berbantuan Teknologi. Vol 1. Hal $181-183$.

Mafidah, Evi. (2021). Video Pembelajaran Matematika pada Materi Dimensi Tiga dengan Menggunakan Pen Tablet. Secondary : Jurnal Inovasi Pendidikan Menengah. Vol 1. Hal 319-321

Risnawati. (2008). Strategi Pembelajaran Matematika. Pekanbaru: Suska Press.

Sadiman, dkk. (2011). Media Pendidikan. Pengertian, Pengembangan dan Pemanfaatannya. Jakarta : Rajawali Pers.

Sundayana, Rostiana. (2013). Media Pembelajaran Matematika (Untuk Guru, Calon Guru, Orang Tua dan Para Pencinta Matematika). Bandung : Alfabeta.

Zaidah. (2021). Peningkatan Pemahaman dan Kemampuan Peserta Didik pada Materi News Item Text Selama Pembelajaran Daring dengan Metode Discovery Learning di SMAN 1 Malinau. Language : Jurnal Inovasi Pendidikan Bahasa dan Sastra. Vol 1 : Hal 5356 